\title{
EXPERIMENTAL CAMPAIGN ON THE USE OF THE FLAT JACK TEST IN COB WALLS
}

\author{
ALEJANDRO JIMÉNEZ RIOS ${ }^{1 *}$, MICHAEL GRIMES ${ }^{1}$ AND DERMOT O'DWYER $^{1}$ \\ ${ }^{1}$ Department of Civil, Structural and Environmental Engineering \\ Trinity College Dublin (TCD) \\ College Green, D02 Dublin, Ireland \\ e-mail: jimnezra@tcd.ie, https://www.tcd.ie/civileng/people/doctoral-students/alejandro-jimenez- \\ rios.php (*corresponding author)
}

Keywords: Conservation, Minor Destructive Tests (MDT), Earthen Architecture, Mechanical Properties

\begin{abstract}
The flat jack test is one of the most used investigation techniques in the area of architectural heritage conservation. Unfortunately, there are no results available in the literature reporting the use of the flat jack technique in cob walls. This paper presents the firs experimental campaign performed to validate the use of this Minor Destructive Technique (MDT) to determine the levels of stress in cob walls and their mechanical properties. Furthermore, three workshops organized and facilitated with the aim of increasing public engagement and awareness towards the conservation of earthen vernacular architecture are also presented.
\end{abstract}

\section{INTRODUCTION}

The flat jack test was first developed and applied in the study of rock mechanics [1]. After its adoption in the years 1980s by Rossi for its use in masonry walls, the method has been used by several researchers to determine the level of stresses and the mechanical properties of ashlar, brick and stone masonry, as well as of, adobe and rammed earth walls [2].

Cob is an earthen construction technique that was traditionally used in at least 18 European countries [3], and many others around the world [4], to build, mainly, dwellings and farming buildings. Cob elements are as well present in 29 UNESCO World Heritage Sites as highlighted by the World Heritage Inventory of Earthen Architecture [5].

Despite the widespread presence of cob buildings and the popularity of the flat jack test among conservation engineers, no results have ever been reported on the application of this Minor Destructive Technique (MDT) on such kind of wall typology.

This paper presents the description of the first laboratory experimental campaign to assess the feasibility of the application of the flat jack test to determine the stress levels and the mechanical properties of cob walls.

\section{EXPERIMENTAL CAMPAIGN}

The experimental campaign started in the spring of 2018 with the literature review of the topic (see Figure 1 where the followed methodology is presented in a diagram form). 


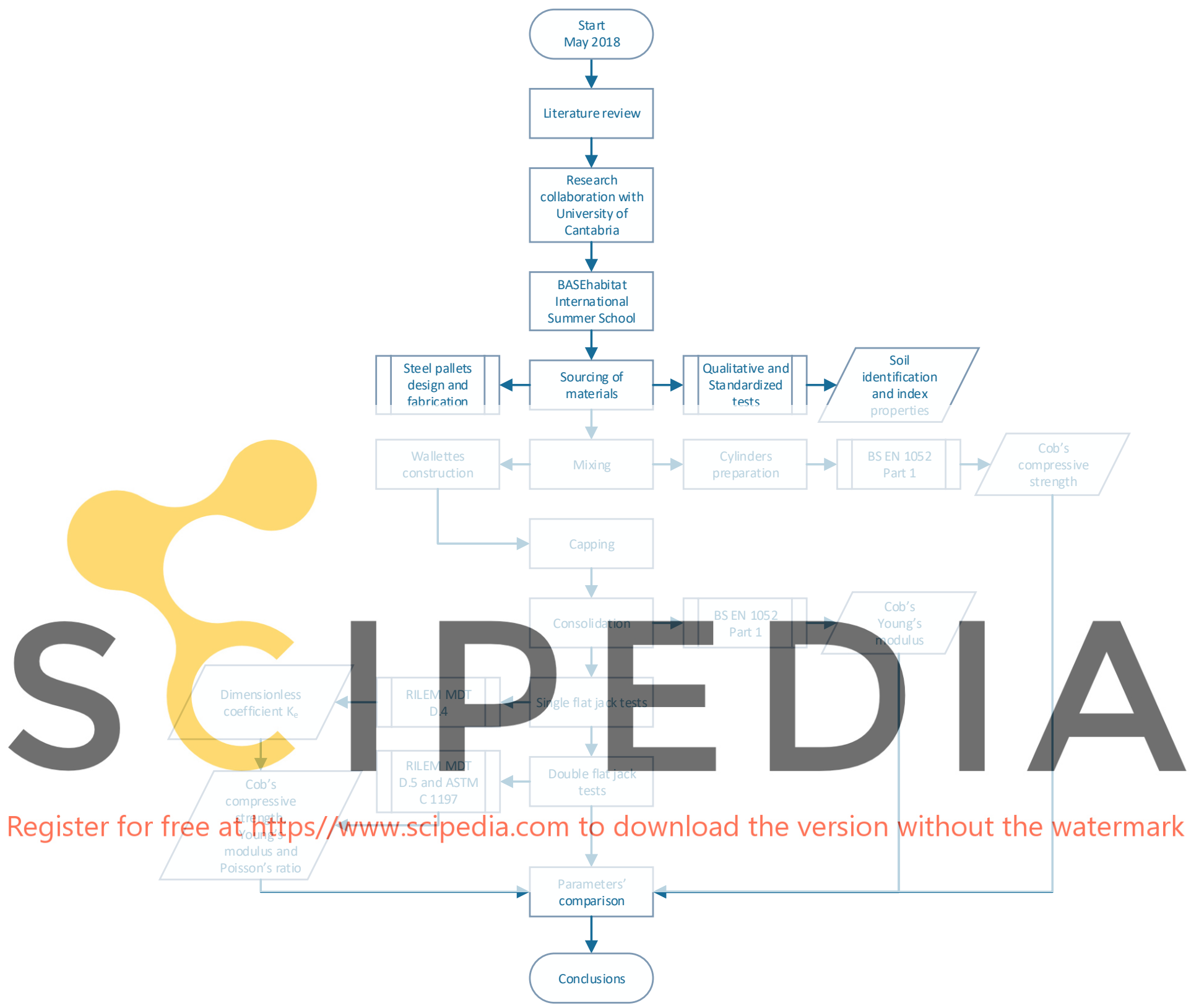

Workshops, public engagement and awareness increase

Figure 1: Methodology's steps implemented during the experimental campaign.

The necessary technical knowledge to implement the flat jack test technique was acquired thanks to a research collaboration carried out at the University of Cantabria (UC) in Santader, Spain, during the months of June and July 2018. The expertise and know-how acquired during this period proved to be invaluable for the success of the flat jack tests performed in this experimental campaign.

The traditional cob construction technique was learned by the first author during his 
participation at the International BASEhabitat Summer School organized by the University of Linz, Austria. In this event, experienced earthen builders and researchers, taught the traditional skills used in France, UK and Ireland to build vernacular cob walls and these skills were used to build the wallettes at the laboratory of Civil Structural and Environmental Engineering (CSEE) in Trinity College Dublin (TCD).

The basic raw materials needed to build a cob wall are: straw, water and soil. It was intended to build the wallettes of this experimental campaign in a sustainable way and to try to reproduce the characteristics of a historical cob wall as closely as possible. Thus, materials were sourced locally, and traditional construction methods were used. The selection of the raw materials was based on recommendations provided by several authors [6-12]. Those recommendations are mainly concerned with the water quality, the type and the length of the straw, the clay content and the Particle Size Distribution (PSD) of the soil.

Qualitative soil tests have been traditionally used by vernacular builders, who had no access to complex equipment and laboratory facilities, to assess the suitability of the material for earthen construction purposes. These tests are highly related to the human senses and provide basic information about the constitution of the soil and of its behavior. The advantages of qualitative tests are their simplicity, easiness, low-cost and their relatively fast data obtainment. On the other hand, the interpretation of qualitative tests is subjective and depends on the experience and personal judgement of the test performer. Qualitative tests were performed on a sample of soil collected directly from the soil supplier yard. Those tests are shown in Figure

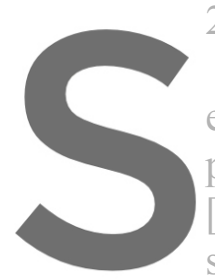
2.

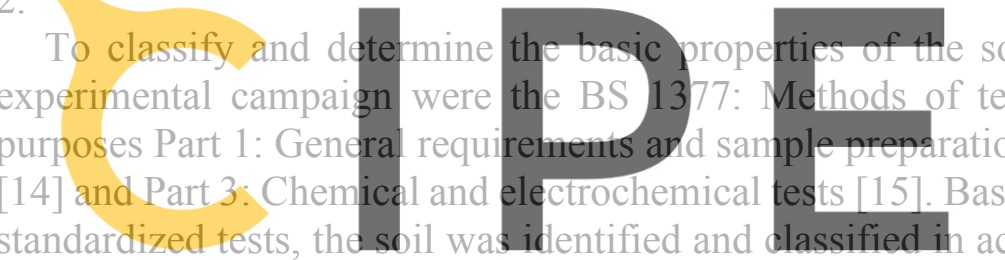

Geotechnical investigation and testing - Identification and classification of soil Part 1

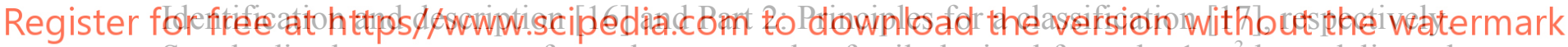
Standardized tests were performed on a sample of soil obtained from the $1 \mathrm{~m}^{3}$ bags delivered by the soil supplier.

The components' mixing proportions were based on recommendations given by several authors [11-12-18-19] and adopted to the physical constrains of the laboratory of CSEE in TCD. Thus, mixes of $80 \mathrm{~kg}$ of soil with $1.2 \mathrm{~kg}$ of straw and $12 \mathrm{~kg}$ of water were adopted. Each one of the mixes provided enough material to build a layer of approximately $10 \mathrm{~cm}$ height. Thus, in average, 10 mixes were necessary to build each one of the wallettes with approximate dimensions of $100 \mathrm{~cm}$ length by $100 \mathrm{~cm}$ height by $40 \mathrm{~cm}$ thickness. 


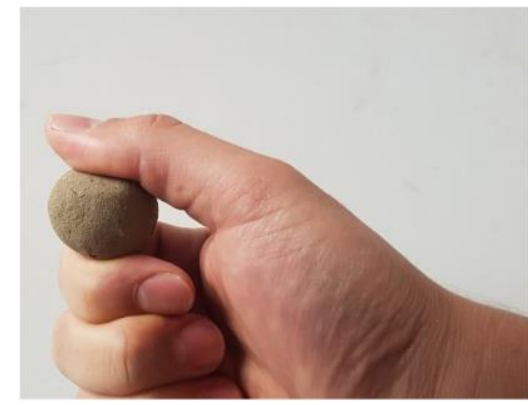

(a)

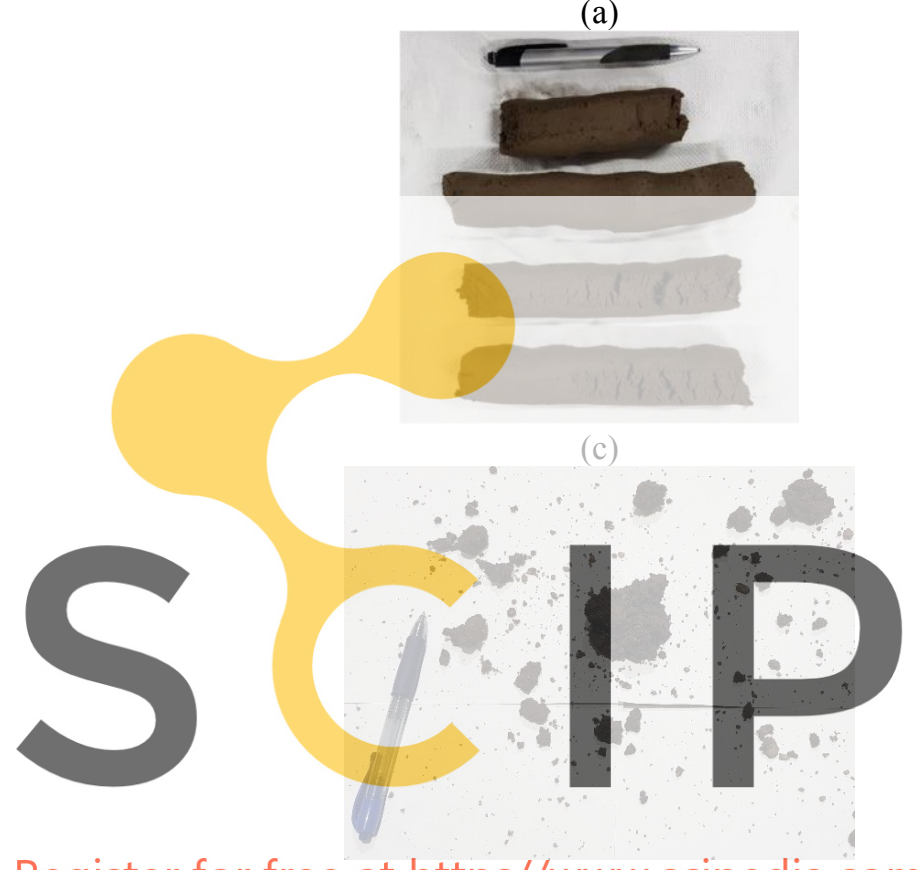

Register for free at https//wasw.scipedia.com to download the version without the watermark

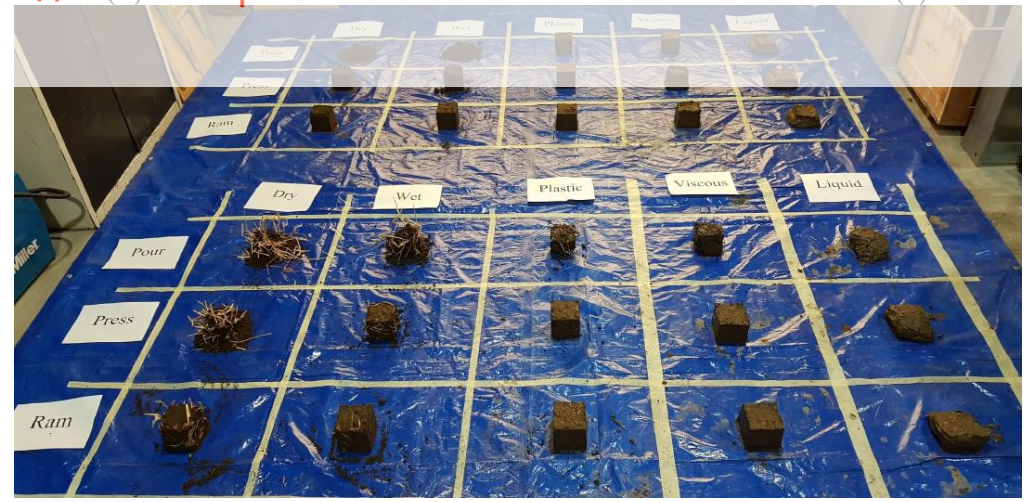

$(\mathrm{g})$

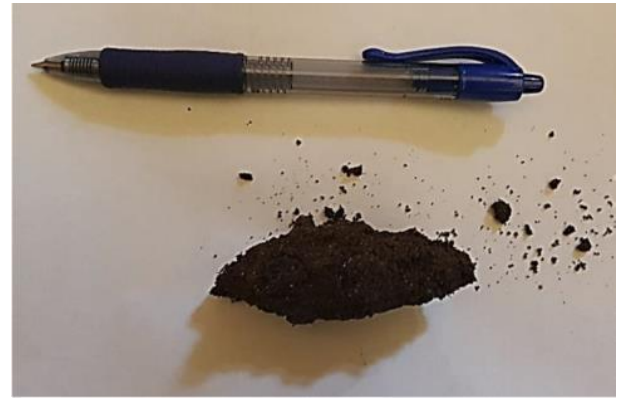

(b)

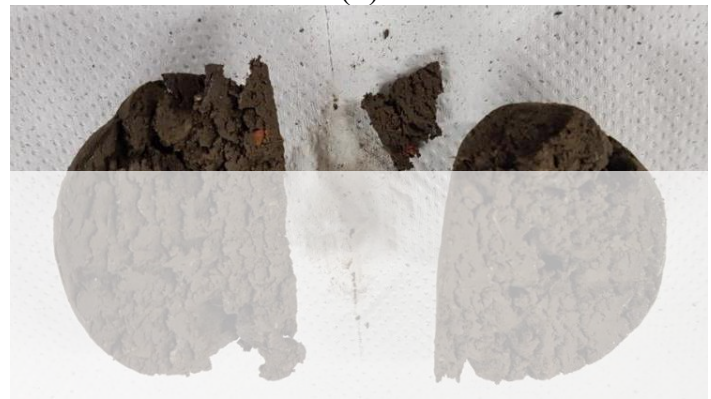

(d)

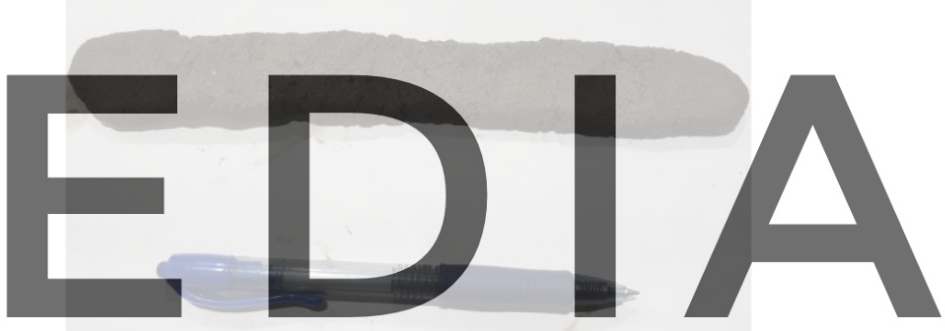

Figure 2: Qualitative tests performed, namely, (a) pressing ball, (b) touching, (c) cigar, (d) ball cutting, (e) ball dropping, (f) ribbon and (g) Carazas.

The cob wallettes were built on top of steel pallets to facilitate their transportation around the laboratory. Moreover, a top cap was also fabricated with the idea of connecting it with the 
bottom pallet through threated steel bars and applying low compression force during transportation of the wallettes in order to avoid damaging the wallette due to vibrations that might have led to tensile stresses and therefore the opening of cracks. The steel bottom pallets and top cap were designed using a universal beam (UB) $533 \times 210 \times 82$ section (this section was selected to accommodate the dimensions of the cob wallettes and of the pallet jack used in the laboratory). The bottom pallets were perforated at four locations of their flanges to allow the pallet jack to go beneath them. On the other hand, four C-channel section segments were welded to the web of the top cap to act as points of attachment and provide symmetric points of attachment for the crane's chains, thus allowing the lifting of the wallettes. Finally, four pieces of hollow steel tube were welded to both bottom and top UB flanges to provide the points of connection of the threaded bars.

Once the loam was readily mixed, it was divided into balls of approximately 20 to $30 \mathrm{~cm}$ in diameter. The balls were thrown to the steel pallet to build the first $10 \mathrm{~cm}$ layer of the first 30 $\mathrm{cm}$ lift of each one of the wallettes. Balls were thrown being careful to assure overlapping with previous balls and moulded with the fingers to try to fill all voids. The lifts were built a couple of $\mathrm{cm}$ bigger than the marked area of 0.4 by $1.0 \mathrm{~m}$ on the steel pallets with the aim of avoiding having any holes or cavities at the faces after the pairing of the surfaces. Once the bottom lifts achieved the desired height their top surface was marked with the fingers in order to create holes that would improve the interlocking with upper lifts. The pairing of each one of the wallettes' lifts was done four or five days after their construction and before adding the next lift

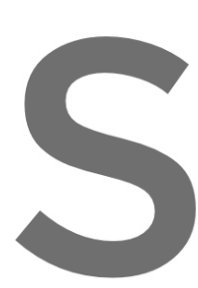
on top of them. A timber saw and a bubble level was first lift was paired the the sawn faces. Furtherin used as guidance ro ac
second lift was added
rmore, the top surface
last lift. Again, after a
timber saw and the b
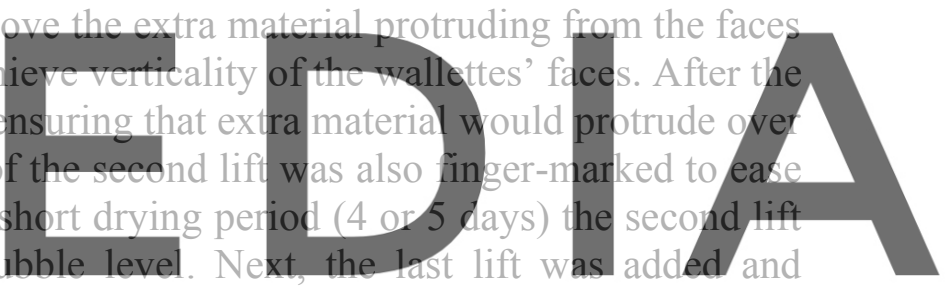
was paired using the tibsequently paired. They wallettes were built in three lifts, $30 \mathrm{~cm}, 30 \mathrm{~cm}$ and $40 \mathrm{~cm}$ height

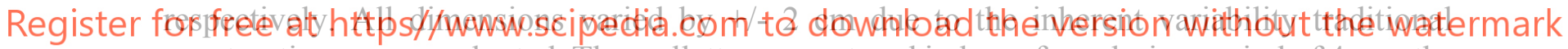
construction process adopted. The wallettes were stored indoors for a drying period of 4 months under uncontrolled environmental conditions. A diagram of the built specimens is presented in Figure 3.

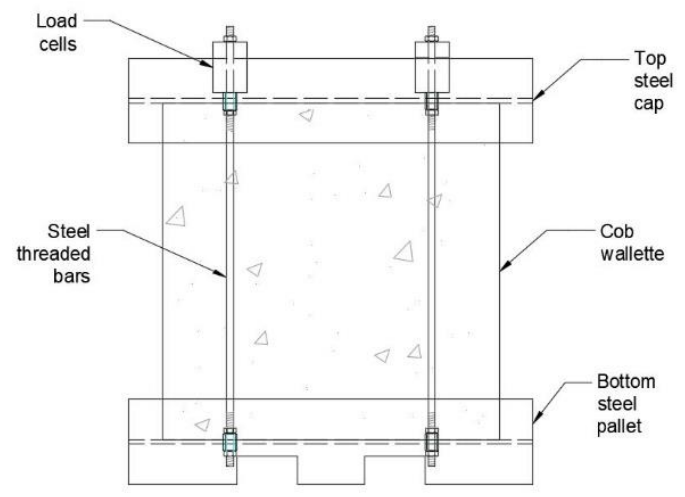

(a)

Figure 3. Diagram of the built cob wallettes. 
To ensure a horizontal top surface and consequently an even distribution of the compressive load the wallettes were capped with a layer of cement mortar. Timber formwork was clamped to the wallettes and levelled with the help of a bubble level. The cement mortar was placed on top of the wallette and levelled with a straight piece of timber. The finished surface was completely flattened and cured for several days with the application of a wet hessian cloth.

In a parallel process, six cylinders were prepared, using randomly sampled material from the cob wallettes' mixes, with the objective of performing compressive tests on them to estimate cob's compressive strength. This data would give a point of reference to establish the consolidation and test loads to be applied to the wallettes. The cylinders were prepared using $15 \mathrm{~cm}$ diameter by $30 \mathrm{~cm}$ length steel molds. The mold was filled with six or seven layers of cob. Every layer was tamped by hand, pressing with the fingers to try to fill all the voids. This preparation procedure is similar to the one implemented by Pullen and Scholz [20].

After a four-months drying period the pre-consolidation of the wallettes began. The preconsolidation load applied to the wallettes was fixed taking as reference the mechanical properties obtained from the cob cylinders tested in this experimental campaign. It was decided not to exceed the apparent yield point of cob which corresponded approximately to $30 \%$ of the computed average compressive strength of the cylinders $(0.7 \mathrm{MPa})$. Therefore, the wallettes were subjected to a consolidation force of $84 \mathrm{kN}+/-1 \mathrm{kN}$.

The loading set-up consisted in 4 treaded bars fixed at the bottom and top steel pallets which were tensioned by tightening the nuts at the top. The tightening of the nuts was performed manually, in increments of approximately $2 \mathrm{kN}$ per bar, and the initial loading process, going from 0 up to $85 \mathrm{kN}$ to ok approximately 15 to 20 min for each wallette. The tension forces thas
applied caused the shortening of the bars, deformation that subsequently translated into a
compressive force applied to the cob wallettes. Therefore, loads were applied slightly
eccentrically but in a symmetric way as the points of anchorage of the bars were located at the
external faces of the steel pallets flanges. A load cell was installed between each point of support at the top steel pallet and the nut to measure the load transferred for each one of the bars to the

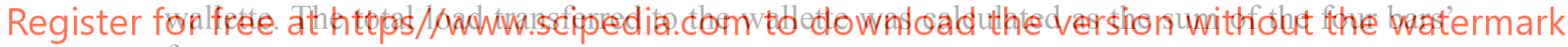
forces.

Four linear variable differential transformers (LVDT) were attached to the wallettes' faces, two in the front and two in the back, to measure the deformation caused by the compressive forces. The LVDT's were pinned through the material using stainless-steel pins of roughly 5 to $6 \mathrm{~cm}$ length by $2 \mathrm{~mm}$ diameter. The points of support were held in place at an initial distance of roughly $30 \mathrm{~cm}$ at the middle third of the specimens. This arrangement was in agreement with BS EN 1052 Part 1 [21].

The procedures described in ASTM C 1196 Standard test method for in-situ compressive stress within solid unit masonry estimated using flat jack measurements [22] and in RILEM LUM D2/MDT D4 In-situ stress tests on masonry based on the flat jack [23-24], specialized in masonry walls, were adopted and adapted to perform the single flat jack test in the cob wallettes of this experimental campaign. Similarly, the procedures described in ASTM C 1197 Standard test method for in situ measurement of masonry deformability properties using the flat jack method [25] and in RILEM LUM D3/MDT D5 In-situ stress/strain behavior tests based on the flat jack [26-27], were adopted and adapted to perform the double flat jack test.

The data obtained during the experimental campaign can be consulted elsewhere [28]. 


\section{WORKSHOPS}

As this experimental campaign aimed at increasing awareness regarding the importance of conservation of vernacular architecture, the experimental campaign was used to involve a great number of people and disseminate the acquired knowledge about the subject. Academics, technical staff, researchers, as well as undergraduate students and the general public participated in the different activities developed during this experimental campaign related to the conservation of earthen vernacular buildings and the use of natural materials for sustainable construction purposes.

Two one-day workshops were run. In the first one, undergraduate students were invited to attend a morning presentation on the conservation of earthen vernacular buildings in Ireland and to participate in the construction of the wallettes of the experimental campaign. The second workshop was organized within the framework of the Trinity Green Week 2019. The Trinity Green Week is an annual environmentally themed event with a multitude of events to simulate the mind and engage the soul in creating better world citizens. Both students and the general public were invited to participate in this second workshop. Participants to both workshops are shown in Figure 4 (a) and Figure 4 (b), respectively.

Finally, students of architecture from University College Dublin (UCD) and from the Dublin Technical University (DTU) were invited to the laboratory of TCD. The students were given a presentation on the main aspects of the experimental campaign performed. After this, a tour around the laboratory facilities was conducted where they could see the specimens that were

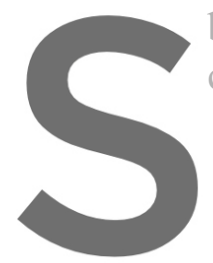
built and tested along campaign (Figure $4($ ) $)$
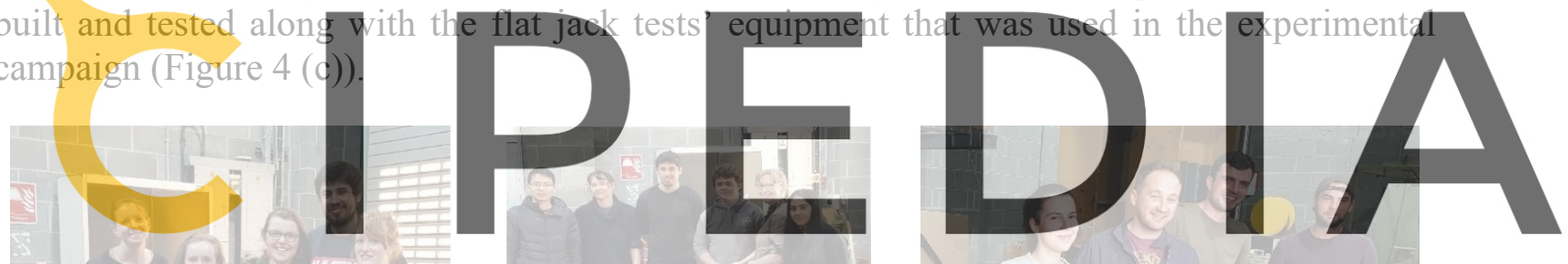

Register for free at https//www.scipedia.com to download the

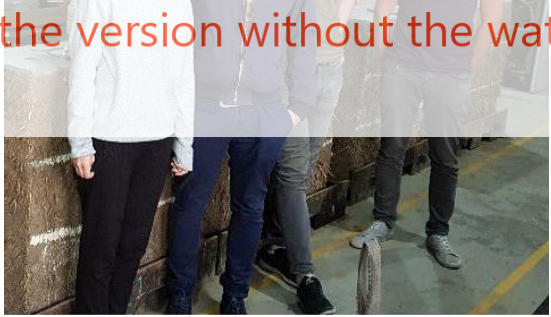

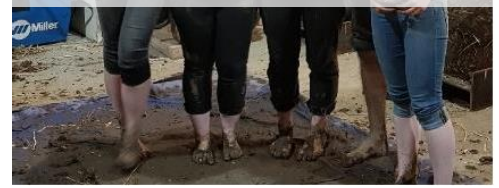

(a)

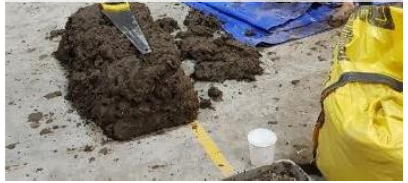

(b) (c)

Figure 4: Cob workshops' participants.

\section{CONCLUSIONS}

The flat jack test is one of the most applied investigation techniques in the area of cultural heritage conservation, where the information obtained with this method is used, to assist in the structural safety evaluation of existent structures. The experimental campaign carried out and presented in this paper provided the first results of a flat jack test ever performed in a cob wall.

Another important part of this research comprised the series of public engagement and awareness increase activities performed around the experimental campaign presented in this work. The discussions that took place during and after the workshops proved to be extremely 
rich, especially due to their multidisciplinary character and the different backgrounds and previous experiences of the participants of the events.

Acknowledgements. This work was supported by the Department of CSEE at TCD. The authors would like to thank all the technical staff of this Department for their invaluable help and support. The authors would also like to thank Professors Luis Villegas and Ignacio Lombillo for hosting the first author at University of Cantabria, Spain, and for sharing with him their experience and know-how with the at jack technique.

\section{REFERENCES}

1. P. B. Gregorczyk Pawełand Lourenço, A review on flat-jack testing. Engenharia Civil, (2000).

2. I. Lombillo Vozmediano, Investigación teórico-experimental sobre ensayos ligeramente destructivos (MDT) utilizados para la caracterización mecánica in situ de estructuras de fábrica del patrimonio construido, Universidad de Cantabria, 2010.

3. M. Correia, L. Dipasquale, S. Mecca, \& K. Akermann, Terra Europae: earthen architecture in the European Union. Pisa: ETS, (2011).

4. S. Piesik, Habitat: vernacular architecture for a changing planet (Thames \& Hudson, 2017).

5. D. Gandreau \& L. Delboy, World heritage inventory of earthen architecture.
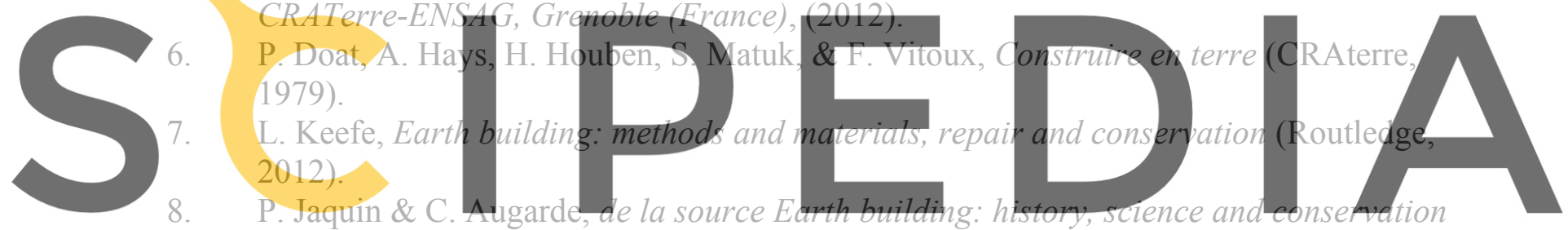
(distributeur IHS BRE Press, 2017).

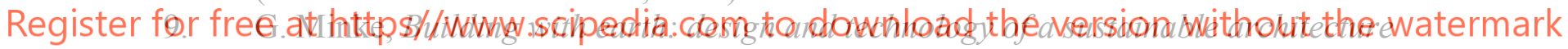
(Walter de Gruyter, 2012).

10. L. Miccoli, U. Müller, \& P. Fontana, Mechanical behaviour of earthen materials: a comparison between earth block masonry, rammed earth and cob. Construction and building materials, 61 (2014) 327-339.

11. E. Hamard, B. Cazacliu, A. Razakamanantsoa, \& J.-C. Morel, Cob, a vernacular earth construction process in the context of modern sustainable building. Building and environment, 106 (2016) 103-119.

12. T. Teixeira, C. Konig, \& U. Schwantner, BASEhabitat Summer School 2018 Handbook (BASEhabitat, 2018).

13. BS 1377-1:2016 Methods of test for soils for civil engineering purposes - Part 1: General requirements and sample preparation (London, United Kingdom: British Standards Institution, 2016).

14. BS 1377-2: 1990 Methods of test for soils for civil engineering purposes - Part 2: Classification tests (London, United Kingdom: British Standards Institution, 1990).

15. BS 1377-3: 2018 Methods of Test for Soils for Civil Engineering Purposes - Part 3: Chemical and electro-chemical tests (London, United Kingdom: Brisith Standards Institution, 2018). 
16. BS EN ISO 14688-1:2018 Geotechnical investigation and testing. Identification and classification of soil. Identification and description (London, England: British Standards Institution, 2018).

17. BS EN ISO 14688-2:2018 Geotechnical investigation and testing. Identification and classification of soil. Principles for a classification (London, England: British Standards Institution, 2018).

18. F. McDonald \& P. Doyle, Ireland's earthen houses (A. \& A. Farmar, 1997).

19. L. Watson \& K. McCabe, The cob building technique. Past, present and future. Informes de la Construccion-Revista, 63 (2011) 59.

20. Q. M. Pullen \& T. V Scholz, Index and engineering properties of Oregon cob. Journal of Green Building, 6 (2011) 88-106.

21. BS EN 1052-1:1999 Methods of test for masonry. Determination of compressive strength (London, England: British Standards Institution, 1999).

22. ASTM C1196-09 Standard test method for in situ compressive stress within solid unit masonry estimated using flatjack measurements (West Conshohocken, PA: ASTM International, 2009). https://doi.org/10.1520/C1196-09.

23. RILEM LUM D2 In-situ stress tests on masonry based on the flat jack (RILEM TC, 1994). https://doi.org/10.1617/2351580117.157.

24. RILEM MDT. D.4 In-situ stress tests based on the flat jack (RILEM, 2004). https://doi.org/10.1007/BF02481588.

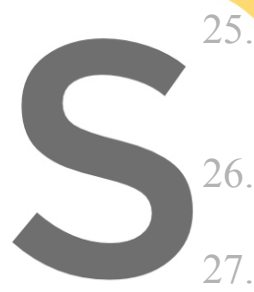
ASTM C1 197-14a Standard test method
deformability properties using the flatjack
International, 2014). https://doi.org/10.1
RILEM LUM D3 In-situ strength/elastic
(RILEM TC, 1994). https://do1.org/10.1
RILEM MDT. D.5 In-situstress-strain beh
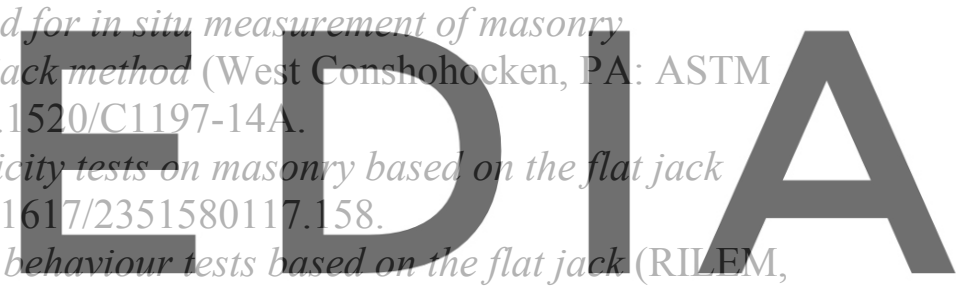

2004). https://doi.org/10.1007/BF02481589.

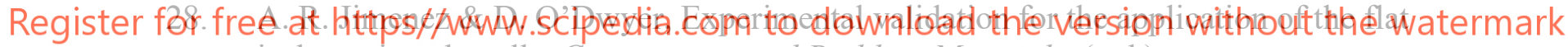
jack test in cob walls. Construction and Building Materials, (n.d.). 